\title{
PENERAPAN PENDEKATAN SCIENCE TECHNOLOGY AND SOCIETY (STS) DALAM PEMBELAJARAN SAIN DI MI
}

\author{
Agus Mukti Wibowo
}

Dosen pada program studi PGMI UIN Malang

\begin{abstract}
Model, strategy or approach, which applied in teaching, can influence the process of learning. It assumed that the right approach can increase the ability of students in understanding the concepts which are studied. Generally, the teaching in MI has different characteristic from the elementary school. Creativity or modification model approaches needed to apply the teaching and learning of science in MI. One of the applicable approaches in science teaching, which is appropriate with MI characteristic, is STS. The implementation of STS approach has the opportunity to bring the Islamic teachings such as moral-ethic.
\end{abstract}

Keyword: Approach, concept, STS

\section{A. Pendahuluan}

Pemahaman merupakan salah satu faktor penting dalam belajar. Menurut Nakhleh (1992:191) kesulitan-kesulitan dalam memahami konsepkonsep dasar dengan tepat akan menghambat siswa dan mahasiswa dalam mengkaitkan konsep-konsep dasar tersebut dengan konsep-konsep lain yang berhubungan. Dengan penggunaan metode atau strategi belajar yang tepat diharapkan dapat meningkatkan pemahaman siswa dalam mempelajari konsep sain.

Dalam pembelajaran sain, untuk meningkatkan pemahaman siswa sering menjadi masalah tersendiri bagi para guru karena terdapat banyak faktor, baik internal maupun eksternal yang dapat mempengaruhi siswa dalam memahami konsep-konsep sain yang dipelajari. Penerapan metode maupun pendekatan yang tepat dalam pembelajaran diharapkan dapat membantu dalam meningkatkan pemahaman siswa dalam mempelajari konsep sain. Penerapan strategi dan pendekatan dalam pembelajaran akan berpengaruh terhadap hasil yang akan dicapai oleh siswa.

Proses pembelajaran sain yang selama ini sering dilakukan hanya memberikan ceramah atau masih merupakan tranfer ilmu pengetahuan. Model pembelajaran seperti ini kurang sesuai dengan kebutuhuan ataupun kurikulum siswa. Pembelajaran yang masih berpusat pada guru hanya melatih siswa dalam menyelesaikan permasalahan soal-soal dalam buku, dengan kata lain siswa hanya pasif menerima informasi dan menunggu perintah guru. 
Pembelajaran sain memerlukan parsipsi aktif baik secara fisik maupun mental (Astuti, 2008). Seorang guru perlu memperkenalkan lingkungan (masyarakat di sekitarnya) dan peristiwa yang sering dialami oleh siswa dalam kehidupan sehari-hari termasuk dalam kehidupan beragama sehingga dapat meningkatkan daya tarik siswa dalam belajar sain. Selain itu guru harus bisa membuat pertanyaan serta membuat hubungan ilmu pengetahuan dengan kehidupan beragama dan diharapkan selain memahami konsep yang dipelajari siswa juga memiliki mentalitas agama yang semakin kuat. Tetapi dalam prakteknya, keterbatasan pengetahuan guru baik secara materi bahan ajar, metode atau strategi pembelajaran maupun pengetahuan agama membuat pembelajaran menjadi monoton (membosankan) yang berakibat siswa tidak aktif dan kurang motivasi dalam proses belajar mengajar.

Proses pembelajaran sain yang tepat diharapkan dapat membentuk ketrampilan maupun kemampuan berpikir dalam menemukan pemecahan secara kritis dan rasional berdasarkan permasalahan yang dihadapi dalam kehidupan sehari-hari untuk meningkatkan pemahaman konsep yang dipelajari. Hal tersebut menuntut pendidik (guru) untuk memberikan kesempatan kepada siswa untuk menemukan, menguasai dan memiliki konsep sendiri dengan tepat berdasarkan permasalahan yang dialami siswa dalam kehidupan yang dialaminya.

Pembelajaran sain di tingkat MI seharusnya dilakukan dengan menggunakan suatu pendekatan yang sesuai dengan apa yang dipelajari siswa MI. Pembelajaran MI, memiliki kuantitas pembelajaran dalam bidang agama yang lebih banyak jika dibandingkan dengan sekolah dasar pada umumnya. Untuk itu perlu adanya suatu inovasi dan kratifitas pendekatan pembelajaran yang sesuai dengan karakteristik pembelajaran di MI.

Model pembelajaran yang sering diterapkan dalam pembelajaran adalah konstruktivis. Salah satu model atau pendekatan pembelajaran yang berdasarkan konstruktivisme adalah pendekatan Science Technology and Society (STS) atau Sain Teknologi Masyarakat (STM). Pembelajaran STS didasarkan pada munculnya isu atau masalah yang ditemui dalam masyarakat atau lingkungan sekitarnya. Siswa melakukan diskusi terhadap isu atau permasalahan yang terjadi di masyarakat dengan teman atau guru, mencari informasi dari pakar bila belum diketemukan pemecahannya. Kegiatan seperti ini diharapkan kelak akan membentuk manusia yang tanggap terhadap sains, teknologi dan lingkungan sosialnya.

Pada pembelajaran dengan pendekatan STS terjadi lintas disiplin ilmu dalam memecahkan masalah atau isu yang berkembang. Tujuan utama pembelajaran dengan pendekatan STS adalah untuk menghasilkan pembelajar yang berkepribadian dan dapat mengambil keputusankeputusan penting mengenai masalah yang terjadi dalam masyarakat serta dapat menentukan sikap, mengambil tindakan sebagai akibat dari 
keputusan tersebut (Iskandar, 2004). Dalam penggunaan pendekatan STS siswa diikutsertakan dalam penentuan tujuan, perencanaan, prosedur pengumpulan data/ informasi dan dalam proses evaluasi. Dengan pendekatan STS siswa dapat belajar melalui penelitian ilmiah, di mana siswa mencoba dan berpikir realistik dengan menggunakan langkahlangkah metode ilmiah.

Dalam proses pembelajaran tingkat madrasah, hal yang perlu diperhatikan guru adalah bahwa siswa memiliki pegetahuan awal yang diperoleh dari interaksi dengan lingkungan. Untuk itu guru perlu menggali dan mengkonstruk kemampuan siswa. Untuk mengantisipasi kesalahan konsep yang mungkin terjadi diperlukan pendekatan pembelajaran yang dapat membantu siswa memahami konsep sains sekaligus mengembangkan kemampuan konsep tersebut dalam kehidupannya sehari-hari.

\section{B. Pendekatan Science Technology Society (STS) dalam Pembelajaran Sains di MI}

Sains atau Ilmu Pengetahuan Alam merupakan segala sesuatu tentang alam semesta yang secara sistematis merupakan ilmu pengetahuan baik berupa fakta, prinsip maupun konsep tentang alam semesta. Pembelajaran sains di tingkat dasar atau madrasah setidaknya meliputi: fiska, biologi, bumi dan antariksa serta IPA terpadu.

Pembelajaran sain di tingkat dasar (SD/MI) merupakan awal penanaman konsep dasar tentang pengetahuan alam sekitar serta permasalahannya. Seperti yang kita ketahui bahwa pembelajaran sain di tingkat MI seharusnya dilakukan dengan menggunakan suatu pendekatan yang sesuai dengan apa yang dipelajari siswa MI. Dalam pembelajaran MI, bidang agama memiliki kuantitas pembelajaran yang lebih banyak jika dibandingkan dengan sekolah dasar pada umumnya.

Penggunaan pendekatan yang dilakukan dalam pembelajaran sains di MI memerlukan penyesuaian sesuai dengan karakteristik MI yang memiliki kuantatitas pembelajaran di bidang agama lebih banyak. Pendekatan pembelajaran yang bisa digunakan adalah dengan memodifikasi pendekatan STS didasarkan dengan ajaran agama Islam. Penggunaan pendekatan pembelajaran ini diharapkan, selain mampu meningkatkan pemahaman terhadap konsep sain yang dipelajari, siswa juga dapat menerapkan ajaran-ajaran agamanya dalam kehidupan seharihari dan menjadi seorang muslim yang memiliki intelektualitas tinggi.

Siswa akan memiliki motivasi belajar yang cukup tinggi jika siswa diberikan kesempatan mengembangkan kemampuan dan mengekplorasi permasalahan yang dihadapi dalam kehiupan sehari-hari. Salah satu contoh permasalahan atau isu yang berkembang di masyarakat adalah tentang halal atau haram dari bahan-bahan yang terdapat dalam makanan 
dan minuman. Pengetahuan siswa tidak boleh hanya terbatas berkembang pada pengetahuan tetang bahan-bahan yang digunakan dalam bahan makanan atau minuman atau pengetahuan dari sisi sain saja. Pengetahuan siswa harus dikembangkan dengan terus menggali dari sisi pengetahuan yang lain, misalnya tentang hubungannya bahan makanan atau minuman tersebut dengan kesehatan, lingkungan atau tentang halal/haramn bahan tersebut. Hal tersebut tentu dapat menimbulkan pertanyaan, misalnya "jika bahan makanan atau minuman tersebut diharamkan apakah menimbulkan efek yang buruk bagi kesehatan?", atau bagimana efek dari bahan yang diharamkan menurut ajaran agama Islam tehadap kesehatan tubuh, atau lingkungan di sekitarnya? Rasa keingintahuan ini harus terus dipupuk sedemikian rupa yang pada akhirnya dapat meningkat motivasi dan pemahaman siswa terhadap konsep sains secara utuh (sain, teknologi masyarakat dan agama).

Pendekatan pembelajaran yang sesuai dengan kondisi seperti di atas adalah dengan menggunakan pendekatan yang memiliki kesesuaian dengan kondisi nyata (isu/permasalahan yang berkembang) dalam kehidupan sehari-hari. Untuk itu perlu adanya penggunaan pendekatan dengan kreasi, modifikasi atau penggabungan dengan karakteristik pembelajaran di MI. Salah satu pendekatan yang bisa digunakan adalah pendekatan STS dengan dilandasi ajaran agama Islam. Pendekatan pembelajaran ini menuntut seorang guru untuk menghadirkan isu atau permasalahan yang ada di masyarakat, karena dimungkinkan siswa masih belum mampu mengidentifikasi permasalahan tersebut dengan baik serta mencari keterkaitan ajaran-ajaran agama Islam. Dengan adanya bimbingan seorang guru, memungkinkan siswa akan terlatih untuk selalu kritis dan kreatif terhadap isu atau permasalahan yang berkembang di masyarakat dan mencari pemecahannya berdasarkan ajaran agama Islam.

\section{Konstruktivisme}

Konstruktivisme adalah suatu paham belajar yang menganut paham bahwa manusia membangun (mengkonstruk) pengetahuan dan mencoba memberi arti sesuai dengan pengalamannya. Pengetahuan bukan tiruan dari realitas, bukan juga gambaran dari dunia kenyataan yang ada. Pengetahuan merupakan hasil dari konstruksi kognitif melalui kegiatan seseorang dengan membuat struktur, kategori, konsep, dan skema yang diperlukan untuk membentuk pengetahuan tersebut.

Jika behaviorisme memandang pembelajaran adalah usaha mengajarkan (transfer) berbagai disiplin ilmu pengetahuan dan menekankan pada hasil bukan proses belajar mengajar, maka konstruktivisme memandang pembelajaran adalah proses mengkonstruksi dan bukan menerima pengetahuan. Pembelajaran konstruktivis menekankan pada perkembangan konsep dan pengertian yang mendalam, pengetahuan sebagai konstruksi aktif yang dibuat siswa atau menekankan 
pada proses bukan pada hasil belajar. Jika seseorang tidak aktif membangun pengetahuannya, maka tetap tidak akan berkembang pengetahuannya. Suatu pengetahuan dianggap benar bila pengetahuan itu berguna untuk menghadapi dan memecahkan persoalan atau fenomena yang sesuai.

Pengetahuan tidak bisa ditransfer begitu saja, melainkan harus diinterpretasikan sendiri oleh masing-masing orang. Pengetahuan juga bukan sesuatu yang sudah ada, melainkan suatu proses yang berkembang terus-menerus. Dalam proses itu keaktivan seseorang sangat menentukan dalam mengembangkan pengetahuannya.

Menurut Suhadi (2003) dalam pandangan konstruktivis pengetahuan tumbuh dan berkembang melalui pengalaman, pemahaman akan berkembang semakin dalam dan kuat jika diuji dengan pengalaman baru. Pengetahuan dapat dikembangkan melalui dua cara yaitu: (1) Asimilasi yaitu struktur pengetahuan baru dibuat atau dibangun atas pengetahuan yang sudah ada; dan (2) Akomodasi yaitu struktur pengetahuan yang sudah ada dimodifikasi untuk mengakomodasi atau menyesuaikan dengan penglaman baru.

Teori perkembangan pengetahuan pada pendidikan anak-anak yang banyak digunakan dalam program pendidikan sekarang ini didasarkan pada teori perkembangan intelektualitas atau filsafat berfikir Jean Piaget. Menurut Suhadi (2003:) terdapat empat konsep dasar yang diaplikasikan dalam pembelajaran anak yang berimplikasi pada lingkungan, kurikulum, metode dan evaluasi belajar. Keempat konsep dasar tersebur adalah:

\section{a. Skemata}

Skemata merupakan kumpulan konsep yang digunakan ketika berinteraksi dengan lingkungan. Setiap individu akan mengalami perkembangan skemata dengan bertambahnya tingkat usia, perkembangan ini dimungkinkan oleh stimulus-stimulus yang diorganisasikan dalam pikiran. Dengan demikian skemata adalah struktur kognitif yang selalu berkembang, sehingga belajar pada hakekatnya adalah skemata.

\section{b. Asimilasi}

Asimilasi merupakan proses kognitif dan penyerapan pengalaman baru. Asimilasi pada dasarnya tidak mengubah skemata, tetapi mempengaruhi atau memungkinkan pertumbuhan atau perkembangan skemata. Asimilasi adalah proses kognitif individu dalam usahanya untuk mengadaptasikan diri dengan lingkungan yang terjadi secara terus menerus dalam perkembangan kehidupan intelektual anak. Dengan kata lain perluasan skemata dapat dilakukan melalui proses asimilasi. 


\section{c. Akomodasi}

Akomodasi merupakan proses kognitif sesuai dengan pengalaman baru, ayang menghasilkan terbentuknya skemata baru dan berubahnya skemata lama. Asimilasi bersama akomodasi terkoordinasi dan terintegrasi menjadi penyebab terjadinya adaptasi intelektual dan perkembangan intelektual.

\section{d. Keseimbangan}

Poses adaptasi dalam lingkungan setiap anak (individu) akan memerlukan kesimbangan proses asimilasi dan akomodasi. Keseimbangan akan menyebabkan interaksi yang terjadi antara individu dengan lingkungan menjadi efesien. Keseimbangan akan mendorong terjadinya proses akomodasi dalam penambahan atau perubahan konsep-konsep pada setiap individu .

\section{Science Technology and Society (STS)}

Science, Technology and Society (STS) atau lebih dikenal dengan Sains, Teknologi dan Masyarakat (STM) mulai diperkenalkan tahun 1920 di Amerika Serikat. Akan tetapi perkembangannya di Indonesia dimulai tahun 1970 pada bidang sastra, sosial dan budaya. STM dikembangkan oleh sekolah-sekolah yang berbasiskan sains, dikarenakan adanya fokus perhatian pada identifikasi keberhasilan baru, model kurikulum baru, strategi instruksional baru dan pembaharuan yang baru dalam dunia pendidikan terutama pendidikan sains (Iskandar, 1991). Science, Technology and Society (STS) mula-mula berasal dari EE (Enviromental Education) yang dikembangkan di Amerika sebagai upaya untuk menanamkan kesadaran lingkungan kepada siswa sehingga dapat menjaga dan melestarikan lingkungan.

Pada dasarnya pendekatan STS adalah sebagai berikut:

1. Berorientasi pada isu dan masalah yang aktual dalam masyarakat

2. Interdisiplinery, artinya tidak terbatas pada satu disiplin ilmu saja

3. Tidak melihat sains sebagai sesuatu yang terpisah, tapi sains terkait dengan masyarakat atau kehidupan riil

4. Sadar akan masalah/isu lokal atau global

5. Relevansi, artinya harus relevan dengan kehidupan siswa

Oleh karena sering melibatkan lingkungan dalam pembelajarannya, maka STM mengalami perkembangan lebih lanjut. Perkembangan itu menghadirkan suatu metode pembelajaran baru yang sebenarnya tidak jauh berbeda dengan STM, yaitu SETS (Science, Environment, Technology and Society) atau dengan kata lain SaLingTeMas (Sains, Lingkungan, Teknologi dan Masyarakat). Pembelajaran ini mengkaitkan materi pelajaran dengan lingkungan, teknologi dan dampaknya bagi masyarakat. Seperti halnya dengan STM, SaLingTeMas juga memiliki dasar pemikiran untuk sedapat mungkin membawa pemikiran siswa kepada penerapan konsep sains 
dalam bentuk teknologi yang bermanfaat bagi masyarakat tanpa harus menimbulkan kerusakan lingkungan. Pendekatan ini memberi peluang terhadap pemikiran yang lebih mendalam tentang keterkaitan timbal balik antara sains, teknologi, lingkungan, masyarakat maupun bidang ilmu yang lain (sain, sosial, budaya, agama dll).

Menurut Lisdiana (2001) pembelajaran berwawasan SaLingTeMas menekankan pada hubungan antara konsep yang sedang dipelajari dengan keberadaan serta implikasi konsep tersebut dalam unsur lingkungan, teknologi dan masyarakat. Hal-hal yang perlu diperhatikan adalah sebagai berikut:

1. Menggunakan berbagai macam sumber belajar, baik berupa media cetak, elektronik maupun keadaan nyata di sekitar kita.

2. Memberikan peluang kepada peserta didik untuk lebih berperan aktif, sedangkan guru bertindak selaku fasilitator aktif yang selalu memberikan masukan kepada peserta didik, tanpa menyalahkan pendapat siswa.

3. Membawa peserta didik untuk lebih memiliki harga diri, sehingga mereka lebih termotivasi untuk berperan aktif.

4. Menciptakan suasana belajar yang senang dan terhindar dari suasana tegang yang dapat membuat siswa menjadi takut.

5. Mengarahkan dan memberi motivasi kepada siswa, sehingga siswa dapat lebih berpikir kreatif

Menurut Susanto (1998) penerapan pendekatan STM dalam pembelajaran menjadikan seseorang sebagai manusia yang sadar akan sains dan teknologi. Bahkan dimungkinkan siswa tidak hanya memahami sain dan teknologi saja tetpi mampu mengkaitakan dengan disiplin ilmu yang lain, misalnya kesehatan sosial, budaya maupun ajaran-ajaran agama.

Mackinnu (1996) dalam Susanto (1998) juga menyatakan bahwa jika seorang siswa memiliki pengetahuan yang berupa fakta, konsep, prisnsip, hukum dan teori serta menguasai ketrampilan proses, maka ia akan mampu berpartisipasi dalam masyarakat secara aktif. Ciri-ciri siswa yang mengalami pembelajaran dengan pendekatan STM, antara lain:

1. Dapat menerapkan konsep dan proses ilmiah dalam tindakan seharihari.

2. Memahami saling keterkaitan antara Sains, teknologi dan masyarakat.

3. Menyadari manfaat sains dan teknologi bagi manusia dan sekaligus mengetahui keterbatasan yang ada.

4. Menghargai fungsi dan peran sains dan teknologi bagi perkembangan intelektual.

5. Mampu membedakan antara pendapat pribadi dengan bukti ilmiah.

6. Paham akan manfaat penerapan teknologi dan sadar akan keputusan yang melatarbelakangi penerapannya.

7. Mempunyai wawasan yang lebih luas sebagai hasil belajar sains 
Dalam penerapan pendekatan STS dalam pembelajaran sain, guru bersama siswa berupaya untuk mencari isu/permasalahan yang dihadapi dalam kehidupan sehari-hari. Kemudian masalah tersebut didiskusikan dalam kelompok dengan konsep sains yang telah dimiliki siswa di bawah bimbingan guru. Pada pembelajaran ini, diperhatikan juga aspek moral, etika dan nilai yang berkembang di masyarakat untuk menyikapi permasalahan teknologi dan masyarakat. Jadi, menurut Mackinnu (1996) (dalam Susanto 1998:22) bahwa pendekatan STM merupakan pendekatan pengajaran yang berusaha menjembatani ketiga komponen tersebut dan mengajarkannya kepada siswa dalam rangka mempersiapkan calon warga negara yang kreatif dan bertanggung jawab.

\section{Penerapan Pendekatan STS dalam Pembelajaran Sain di MI}

Ilmu pengetahuan tanpa adanya pemahaman agama dapat mengakibatkan seseorang akan lupa akan jati dirinya, bahwa manusia adalah sama dengan alam semesta yang dipelajarinya yaitu sebagai makhluk Allah SWT. Dengan pemahaman sejak usia dini tentang pentingnya pemahaman agama dalam mempelajari sain diharapkan siswa dalam memahami sains tidak melupakan bahwa segala sesuatu yang ada di alam semesta ini adalah penciptaan Allah SWT. Salah satu contoh pemahaman dalam sain yang tidak dilandasi dengan pemahaman agama adalah adanya Teori Darwin yang salah satunya adalah bahwa adanya alam semesta ini merupakan suatu kebetulan dan terjadi karena adanya evolusi.

Pembelajaran sain berdasarkan teori kontruktivis yang memandang bahwa pengetahuan dibagun sendiri oleh anak melalui interaksi yang terjadi dalam kehidupan sehari-hari, yaitu berupa pengetahuan awal dari informasi yang ada di lingkungan. Interaksi ini merupakan perubahan konseptual yang dialami siswa dari informasi yang diperoleh dari lingkungan. Salah satu pendekatan yang didasarkan pada teori konstruktivis adalah pendekatan STS.

Pembelajaran sains dengan menggunakan pendekatan STS yang berabasis kontruktivis dapat diterapkan untuk meningkatkan pemahaman siswa tidak hanya pada pemahaman sain itu sendiri tapi juga membuat siswa menjadi kritis terhadap permasalahan yang terjadi di sekitarnya serta dapat menimbulkan kreatifitas dalam pemecahannya. Pendekatan STS yang mengangkat isu atau permasalahan yang terjadi di sekitar siswa tepat digunakan dalam pembelajaran sain MI karena pada usia tersebut yang pada umumnya antara 7-13 tahun, menurut Dahar (1989) berdasarkan teori belajar Piaget merupakan tahap berfikir konkrit. Pada tahap ini anak dapat berfikir dengan baik jika hal-hal yang dipelajari berdasarkan pada hal-hal yang konkrit atau nyata yang merupakan tahap permulaan dari tahap berfikir rasional. Tahap berfikir konkrit merupakan tahap berfikir logis terhadap pemahaman sesuatu yang nyata tetapi sulit memahami hal-hal 
yang bersifat verbal atau abstrak. Usia anak yang memasuki masa belajar di MI, berdasarkan teori belajar belajar Piaget dalam pembelajaran seharusnya dilakukan dengan menghadirkan hal-hal nyata yang terjadi dalam kehidupan sehari-hari. Akibat dari pembelajaran tersebut anak akan berinteraksi dengan lingkungan maupun masyarakat yang ada di sekitarnya. Interaksi yang terjadi antara anaka dengan lingkungan akan menimbulkan kemungkinan pemahaman yang berbeda pada diri setiap anak. Guru sebagai fasilitator dalam pembelajaran harus mampu membimbing anak sehingga pemahaman yang dimiliki anak sesuai etika, moral yang ada pada masyarakat maupun ajaran agamanya (Islam ).

Pembelajaran sain dengan pendekatan STS didasarkan pada isu/ permasalahan atau pengalaman nyata dalam kehidupan sehari-hari, menuntut seorang guru dalam membimbing siswa khususnya siswa MI agar selalu hati-hati terhadap segala interaksi yang terjadi antara siswa dengan lingkungannya. Pada saat sekarang ini seperti kita ketahui, banyak hal-hal yang terjadi di masyarakat, di mana seharusnya anak diberikan modal pengetahuan yang cukup untuk menghadapinya, misalnya tentang banyaknya jenis makanan, minuman, obat-obatan atau tanaman yang ada di sekitar kita yang sebenarnya tidak diperbolehkan dikonsumsi atau digunakan oleh ajaran agama Islam dan memiliki efek yang jelek bagi kehidupan kita (masyarakat, kesehatan atau lingkungan). Penerapkan pendekatan STS dalam pembelajaran sain MI guru dimungkinkan untuk memasukkan nili-nilai etika, moral maupun ajaran agama Islam sehingga siswa mampu memahami secara utuh konsep sain dan aplikasinya dalam kehidupan di masyarakat.

Pendekatan STS atau STM memungkinkan siswa untuk melakukan observasi yang berkaitan dengan teknologi atau masyarakat yang dialami dalam kehidupan sehari-hari. Dalam pembelajaran menggunakan pendekatan STS siswa secara langsung dilibatkan dalam menentukan tujuan maupun prosedur dalam melakukan kegiatan pembelajaran. Berdasarkan karakteristik pembelajaran konstruktivisme, pembelajaran sain dengan menggunakan pendekatan STS yang dilandasi oleh Islam dapat dilihat dari hal-hal berikut. (1) Pendekatan STS selalu berorientasi pada isu/ masalah yang terjadi di masyarakat. Hal ini diharapkan siswa untuk sadar dan kritis terhadap sesuatu yang terjadi dalam masyarakat dan berlatih secara kreatif mencari pemecahannya sesuai dengan ajaran agama Islam. Selain itu siswa juga belajar untuk dapat memberikan manfaat baik untuk dirinya sendiri maupun untuk masyarakat sesuai dengan ajaran Islam (2) Pembelajaran dengan menggunakan pendekatan STS merupakan lintas disiplin ilmu yang didalamnya termasuk juga ilmu agama. Pelbagai macam disiplin ilmu harus disinergikan untuk mencari solusi yang terbaik. Siswa akan belajar untuk menganalisis permasalahan yang ada di sekitarnya dari berbagai sisi, baik dari sisi kesehatan, lingkungan, sosial, masyarakat maupun agama. Hal ini dimungkinkan 
akan memunculkan pemahaman yang berbeda-beda pada diri setiap siswa. Guru sebagai fasilitator dalam pembelajaran harus dengan bijak membimbing siswa untuk meminimalkaan terjadinya kesalahpahaman yang terjadi pada siswa. Selain itu guru dapat mengkaitkan materi pembelajaran dengan hukum-hukum atau ajaran agama Islam. (3) Pembelajaran sain dengan menggunakan pendekatan STS mengikutsertakan secara aktif siswa maupun guru dalam penentuan tujuan, perencanaan, prosedur pengumpulan data/informasi dan dalam proses evaluasi. Dengan pendekatan STS siswa dapat belajar lebih baik melalui penelitian ilmiah, di mana siswa dapat mencoba dan berpikir realistik sesuai dengan ajaran agamanya dalam menggunakan langkahlangkah metode ilmiah. (4) Pembelajaran yang terjadi harus ada relevansinya dengan kehidupan nyata siswa. Unsur-unsur kehidupan nyata dihadirkan pada siswa, sehingga memungkinkan adanya tranformasi konsep yang memungkinkan terjadinya perubahan konsep pada diri siswa. Dengan bimbingan guru diharapkan siswa mengalami perubahan dari pemahaman yang salah menjadi pemahaman yang benar. (5) Adanya nilai-nilai etika, moral maupun ajaran agama yang dimasukkan dalam pembelajaran sain, sehingga selain memiliki pemahaman tentang sain maupun teknologi, siswa juga memiliki kesadaran terhadap lingkungan dan masyarakat sekitar serta dapat meningkatkan kenyakinan dalam beragama Islam.

Salah satu contoh pembelajaran sain dengan menggunakan pendekatan STS adalah dengan mengangkat isu atau permasalahan tentang adanya jenis tanaman yang yang termasuk dalam psikotropika. Siswa akan melakukan pengamatan tehadap tanaman yang ada disekitarnya maupun mencari jenis-jenis tanaman dari berbagai sumber, misalnya buku atau dari media elektronik. Pengamatan ini membutuhkan ketrampilan psikomotorik dalam berbagai hal, misalnya observai, pengamatan, pengumpulan data yang diamati dari berbagai jenis tanaman, sampai pada akhirnya siswa dapat mengklasifikasikan berbagai jenis tanaman. Tetapi kegiatan di atas hanya untuk pemenuhan dari sisi intelektualitas siswa, bagaimana dari segi spiritualitasnya ? Jika seorang guru memiliki kratifitas dan inovasi tentu dapat dengan mudah membimbing siswa dalam mencari pemecahannya dari berbagai sisi dan diaplikasinya dalam kehidupan sehari-hari. Misalnya, apakah keuntungan tanaman yang diamati dalam bidang kesehatan?, apakah kegunaan tanaman tersebut dalam kehidupan nyata? atau bagaimanakah hukumnya menurut agama Islam jika tanaman tersebut kita makan atau di konsumsi? Seperti kita ketahui bahwa ada beberapa jenis tanaman yang dilarang dikonsumsi baik dari segi kesehatan maupun agama Islam, misalnya tanaman ganja, opium atau yang lainnya. Dengan pembelajaran seperti ini siswa diharapkan siswa tidak hanya mengerti tentang konsep tanaman atau tumbuhan, tetapi juga memahami tentang manfaatnya untuk 
kehidupan. Selain itu, siswa juga dapat memahami bahwa sesuatu yang dilarang oleh ajaran agama Islam memiliki akibat yang kurang baik bagi manusia.

Pembelajaran sain yang dilakukan seperti contoh di atas memungkinkan siswa memahami sain secara utuh, baik dari segi intelektualitas maupun dari segi spiritualias. Pembelajaran sain dengan menerapkan pendekatan STS yang Islami seperti di atas memberikan kesempatan kepada siswa menganalisis suatu isu atau permasalahan tidak hanya dari sain itu sendiri tetapi juga dari berbagai disiplin ilmu termasuk ilmu agama. Dengan kata lain siswa diharapkan dapat menganalisis isu atau permasalahan dari berbagai sisi ilmu yang dikuasainya.

\section{Kesimpulan}

Penerapan pendekatan STS dalam pembelajaran sain MI memungkinkan siswa secara aktif mengkonstruk pengetahuannya. Pendekatan ini juga memungkinkan dimasukkannya pembelajaran tentang etika, moral yang sesuai dengan kondisi masyarakat maupun ajaran agama Islam. Penerapan pendekatan STS yang berbasis konstruktivis pembelajaran sain di MI dapat membantu siswa dalam memahami konsep sain dan melatih siswa dalam menganalisis isu/permasalahan dari berbagai sisi, sain, teknologi, sosial budaya maupun agama.

\section{Daftar Pustaka}

Astiuti, R.N. 2008. "Penggunaan Model Pembelajaran Interaktif Pada Materi Tumbuhan". Jurnal Pendidikan dan Pembelajaran Dasar Madrasah. 1(1): 1-12.

Iskandar, Srini M. 1991. An evaluation of the Science Technology Society Approach to Science Teaching. Desertasi tidak diterbitkan. Iowa University.

Iskandar, Srini M. 2004. Pendekatan Sains, Lingkungan, Teknologi dan Masyarakat. Makalah disajikan dalam Workshop Regional Sosialisasi dan Implementasi KBK pada Madrasyah Aliyah di Malang. 12-16 Januari 2004. Malang : UM

Nakhleh, M.B. 1992. “Why Some Student's Don't Learn Chemistry: Chemical Misconceptions". Journal of Chemical Education, 69 (3): 191195.

Suhadi \& Senduk.A.G. 2003. Konstekstual dan Penerapannya dalam KBK. Malang : UM 